\title{
Ultrastructure of conidia and hyphal cells of Ophiostoma querci isolates with respect to their ageing
}

\section{KRYSTYNA PRZYBYL*, KRYSTYNA IDZIKOWSKA**}

\author{
Institute of Dendrology, Polish Academy of Sciences, 62-035 Kórnik*, Poland \\ Electron Microscopy Laboratory, Adam Mickiewicz University, 60-780 Poznan**, Poland
}

P r z y b y I K., I d z i k o w s k a K.: Ulrastructure of conidia and hyphal cells of Ophiostoma querct isolates with respect to their ageing. Acta Mycol. 32 (1): 13-21, 1997.

Ultrastructural observations of isolates presented in this paper revealed that conidia and hyphae taken from 6-day old and 30-day-old cultures differed in morphology of membranous bodies and occurrence of electron opaque bodies (EOB). Signle Sporothrix conidia of 30-day-old cultures exhibited a shrinkage of cytoplasm and endospores. It is possible that formation of endospores might result in producing extra cell walls to protect the shrinking or fragmenting cytoplasm.

Key words: Ophostoma querci, ageing, senescence, endospores.

\section{INTRODUCTION}

Numerous isolates of Ophiostoma querci (Georg.) Nannf. were obtained from dark-grey and brown discoloured sapwood of the trunks of Quercus robur trees growing in various localities in Poland. Differences in colony morphology, synnematal production and in length of the Sporothrix primary conidia among isolates of $O$. querci were found ( $\mathrm{Prz}$ y b y $\mathrm{l}, \mathrm{M}$ or e le t 1993; Przy b y ł 1995). Investigations performed by Przy by $\nmid$ and I $\mathrm{d} \mathrm{z}$ i k o w s $\mathrm{k}$ a (1995) revealed that endospores could be produced within Sporothrix conidia and hyphal cells of isolates having atypical morphology (aerial mycelium felty and white, synnemata production after 2 months and Sporothrix primary conidia $0-3$ septate, up $40 \mu \mathrm{m}$ ). Of particular interest were the following questions: whether typical isolates of $O$. querci form endospores in similar abundance as atypical ones and whether the endospores are formed by the fungus as a response to senescence or possible degeneration. 


\section{MATERIALS AND METHODS}

Single-spore isolations (142 and 142A) were made using strongly diluted spore suspensions. Petri dishes were examined under low magnifications and small pieces of malt agar (Difco; $\mathrm{pH} 5.4$ ) bearing single conidia were cut out and transferred onto fresh medium. Cultures were incubated at room temperature in daylight. Six days after inoculation aerial mycelium of the studied isolates were mostly scant and white. In a later stage (30-day-old cultures) some floccose mycelium were formed. Synnemata were abundant, arising all over the colony (Fig. 1). Primary conidia which formed by sympodial growth on the apical part of the conidiogenous cells were hyaline, thin - and smooth walled and clavate. Length of the primary conidia ranged from $6.6 \mu \mathrm{m}$ to $19.9 \mu \mathrm{m}$. Observations were performed on 6 and 30-day-old cultures using a JEOL TEM-1200 Ex transmission-electron microscope. For these observations, the method described earlier by P r z y b y I and I d z i k ow s k a (1995) was used. Samples of mycelium growing on malt agar were fixed in $4 \%$ glutaraldehyde with $0.1 \mathrm{M}$ sodium cacodylete buffer for $6 \mathrm{hr}$. Postfixation (for $2 \mathrm{hr}$ ) was performed in osmium tetroxide in the same buffer. Subsequently the material was stained with a water solution of uranyl acetate and then dehydrated in a graded series of ethyl alcohol, acetone and propylene oxide. Samples were embedded in Epon 812. Ultrathin sections were stained with uranyl acetate and lead citrate.

\section{RESULTS AND DISCUSSION}

Ultrastructure of Sporothrix conidia and hyphal cells of 6-day old cultures

Conidia and hyphae of younger (6-day-old) cultures exhibited an electron light cell wall, outside of which electron dense granules were sporadically observed. The cytoplasm was dense and contained minute granules and numerous fibrous vesicles. The latter appeared to be associated with microtubules (Figs. 2,3). The nucleus as oblong or spherical in conidia, whereas in young growing hyphae it was rather elongated (Fig. 4). Internally, the nucleoplasm appeared homogenous. The conidia and each hyphal cell also contained mitochondria, vacuoles, single osmophilic granules and membranous bodies (referred to as membranous structures ( $\mathrm{J} \mathrm{e} \mathrm{ng}, \mathrm{H} \mathrm{u} \mathrm{b} \mathrm{bes}$ 1980) or membrane complex (H o w a $\mathrm{r}$, $\mathrm{M}$ a x w e 11 1975).

Mitochondria appeared to be distributed throughout the cytoplasm and were rather circular in shape, although elongated ones could also be observed, especially in hyphal cells (Figs. 4, 8). 

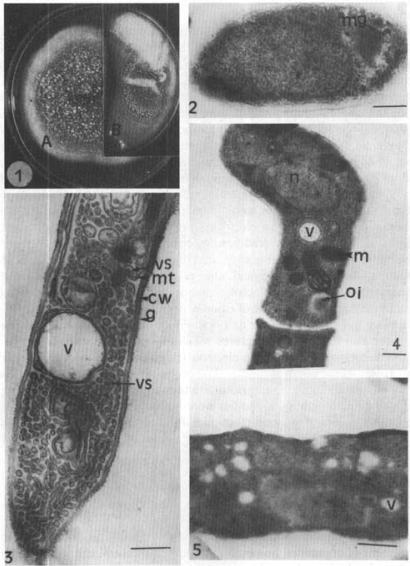

Fig. 1. Culture of Ophiosioma querci isolate

$$
\text { A - 6-day-old, B - 30-day-old }
$$

Figs. 2-5. TEM micrographs of longitudinal sections through conidium (2) and hyphal cells (3-5) of 6-day-old cultures

cw - cell wall, $g$ - electron dense granujes, $m g$ - minute granule, $n$ - nucleus, $m$ - mitochondria, $t-$ vacuoles, of - asmophilic inclusions, $v s-$ vesicles, $m i$ - microtubules. Bars $-10 \mu \mathrm{m}$ 
Single vacuoles present in the young conidia and hyphae were small and translucent (Fig. 5). In the case of hyphae they were most often observed in the subapical regions.

Membranous bodies were neither common in conidia nor in hyphae. These structures contained short membranes in the form of tubuli and small vesicles (Figs. 6,7). Besides this type of membranous bodies there were also those, whose internal matrix of which was fibrillo-granular in appearance, bounded by a double-layered limiting membrane (Fig. 8). These structures resembled electron opaque bodies (EOB), which were frequently observed in the hyphae of Sporothrix schenckii and Ceratocystis stenoceras by G a r r i s o n et al. (1977). Moreover, an apparent association of analogous structures with typical membranous bodies was seen. This close relationship suggests that the succeeding stages of development of membranous structures were observed. Frequently, other type of EOB-like bodies were observed in conidial and hyphal cytoplasm of 10-day-old cultures. These were characterized by an electron dark matrix containing inclusions and an electron light sheath resembling vacuoled area (Figs. 9, 10). The double-layered limiting membrane was observed, depending on the plane of sectioning. It is suggested that membranous bodies or possibly vacuoles undergo morphological changes with electron opaque material accumulating within them. Electron opaque bodies (EOB) were not found in Sporothrix conidia and hyphae of isolates of $O$. querci atypical in morphology (P r z y b y l, I d z i k ow s k a 1995). Besides the above-mentioned bodies, there were also mielin-like structures which formed concentric rings (Fig. 11). Septa in vegetative hyphae were electron transparent and had a central pore (Figs. 7, 11, 12). Spherical bodies known as Woronin bodies were found associated with the pore. The various size tubules and vesicles representing the content of some membranous bodies were associated with plasmalemma (Fig. 12). Some authors suggested (that membranous boidies were involved in polysaccharide synthesis during cell wall formation ( $\mathrm{H}$ a $1 \mathrm{I}$ et al. 1974).

\section{Ultrastructure of Sporothrix conidia and hyphal cells of $30-d a y-o l d$ cultures}

The fungal structures taken from 30-day-old cultures showed a typical complement of organelles, however several ultrastructural changes were noted. Membranous bodies of variable size and shape occurred in the majority cells both conidial and hyphal cells (Fig. 13). With ageing of changes the cells, the membranous bodies underwent progressive degeneration. Inside of them an electron light are increased in size and as a result new type of bodies appeared. This type of bodies were characterized by double membranes enveloping single vesicles and osmophilic inclusions or granularity (Figs. 14, 15). 

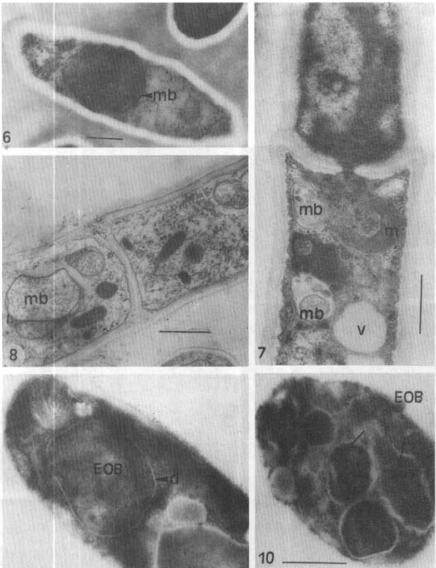

9

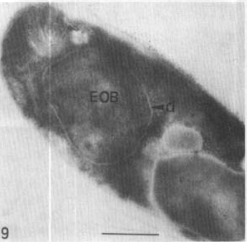

Figs 6-10. TFM micrographs showing various membranous bodies (longitudinal sections through conidium (6) and hyphal cells (7-9), cross section through byphal cell (10) $m b$ - membranous bodies, $m$ - mitochondria, $v$ - vacuoles, EOB - elcctron opaque bodies, $d$ - double layered limiting membrane Bars - 10 fm 

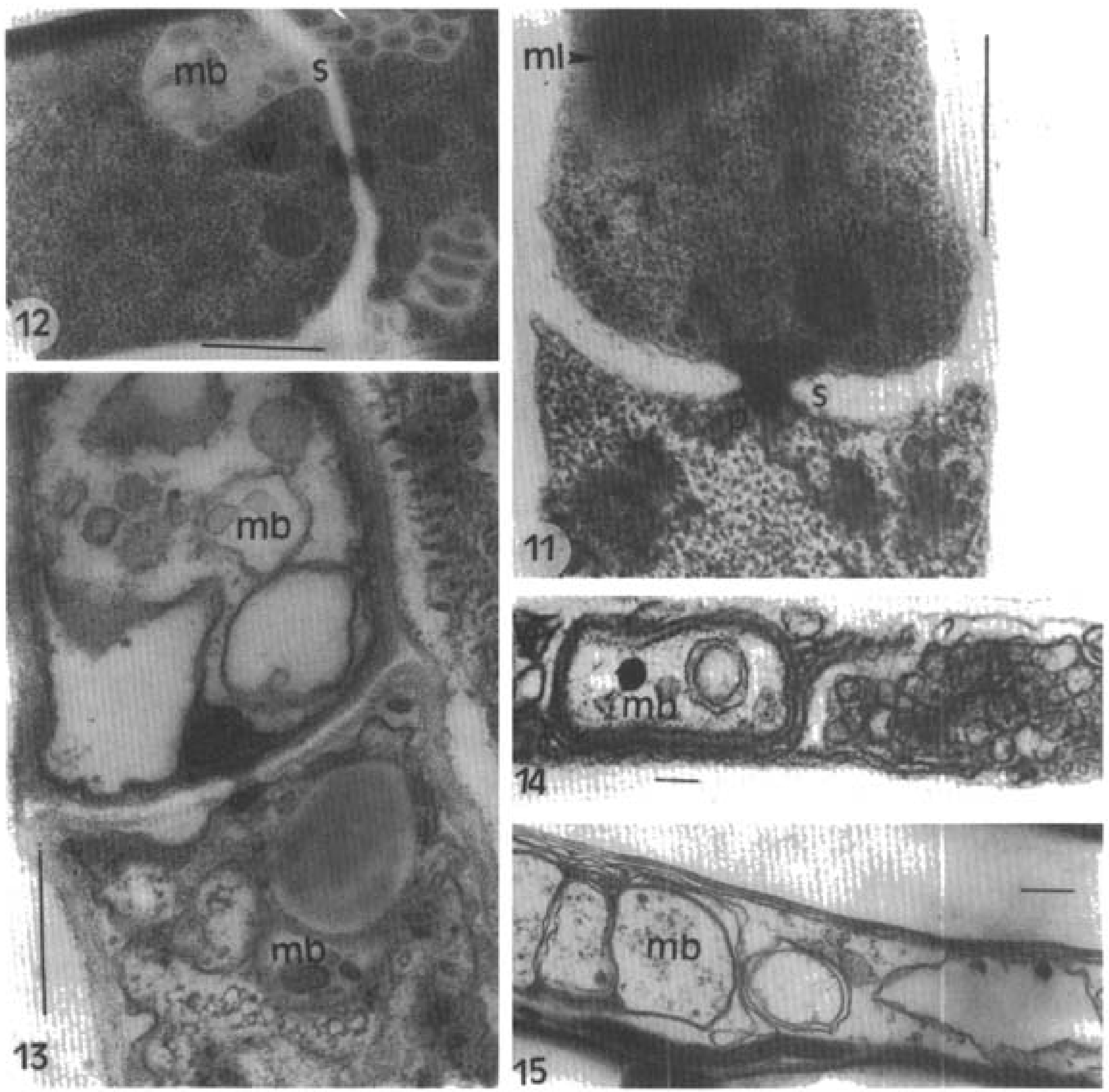

Figs. 11-12. TEM micrographs of melin like structures and organelles associated with septa $s-$ septa, $p$ - pore, $W$ - Woronin bodies, $m b$ - membranous bodies, Bars - $10 \mu \mathrm{m}$ Figs. 13-15. TEM micrographs of longitudinal sections through hyphal cells of 30-day-old cultures $m b$ - membranous bodies. Bars - $10 \mu \mathrm{m}$ 


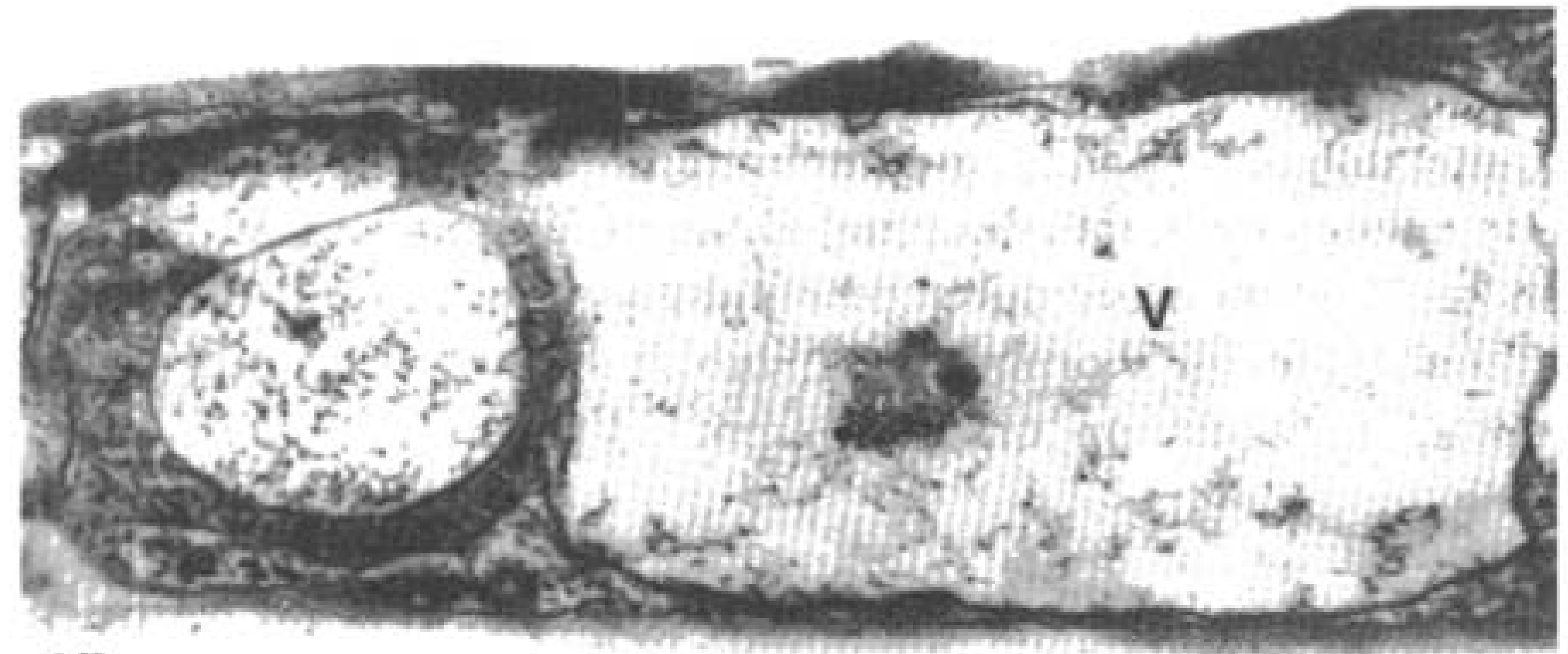

16
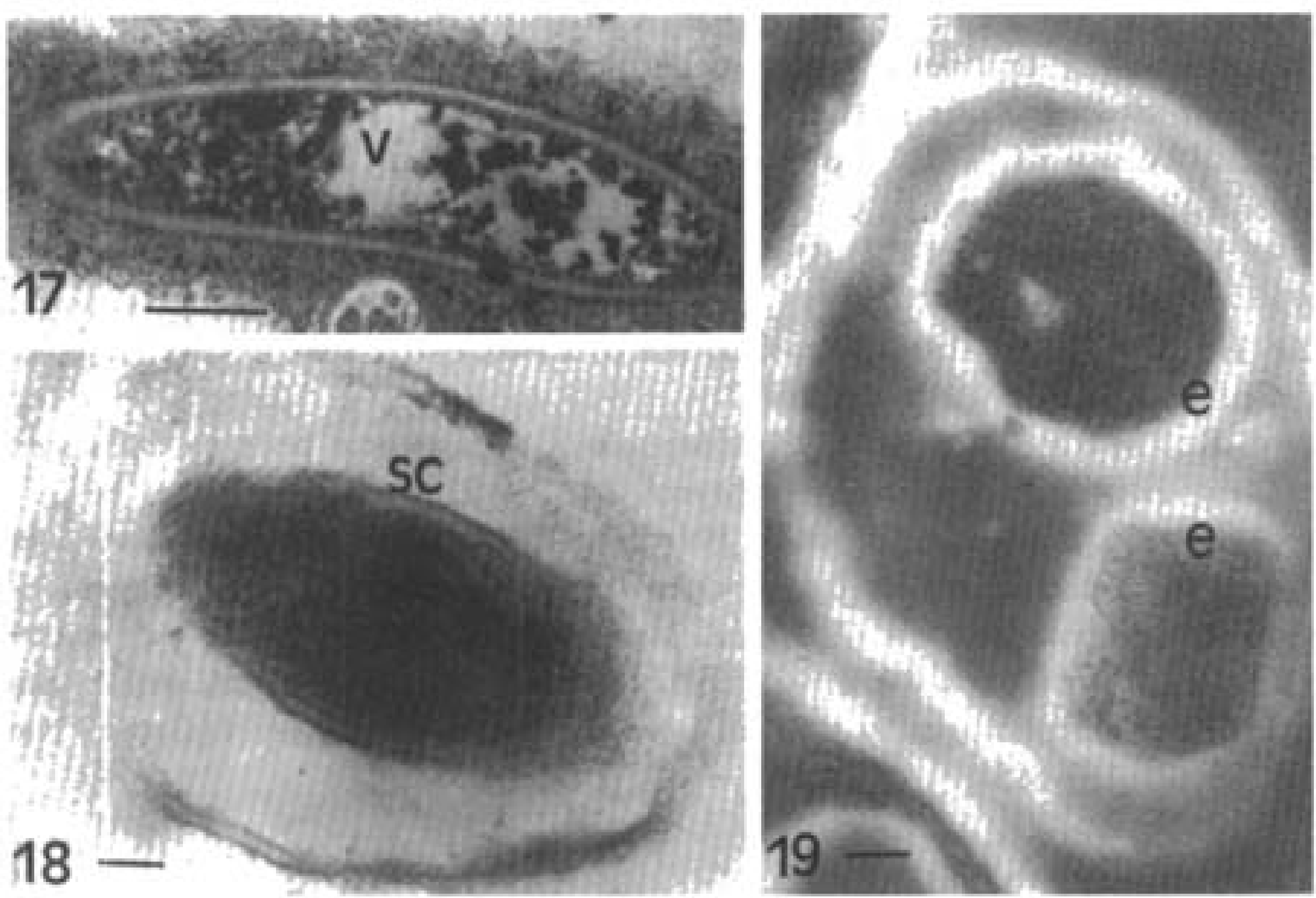

Figs, 16-19. TEM micrographs of longitudinal sections through hyphal cell (16) and conidia (17-19) of 30-day-old cultures

$v$ - vacuoles, se - shrinkage of cytoplasm, $E$ - endospores. Bars $-10 \mu \mathrm{m}$ 
Vacuoles containing different amounts of irregular granularity or osmiophilic inclusions occupied a large part of the conidial and hyphal cell volume (Figs. 16, 17).

Single conidia exhibited shrinkage of cytoplasm (Fig. 18) and endospores (Fig. 19). It is possible that the formation of endospores is a response to senescence or degeneration of cultures. These might result in the producing of extra cell walls to protect the shrinking or fragmenting of cytoplasm. Occurrence of endospores was questioned by $\mathrm{G}$ a $\mathrm{r} r$ i s o $\mathrm{n}$ et al. (1977). In the opinion of these authors the intracellular structures described as endospores in the hyphae of some fungi (e.g. Ophiostoma ulmi) were confused with electron opaque bodies (EOB). The endospores were observed in the majority of conidia and hyphae of isolates of $O$. querci antypical in morphology (P r z y b y l, I d z i k ow s k a 1995). The atypical isolate was send to Prof. B r a s i e r (England) for analysis of rDNA RFLP profiles. He found that "it had a quite different RFLP profile from the healthy, wild-type $O$. querci isolates. In other words, its ribosomal DNA genes may well be altered and on this basis some of its other developmental genes may be altered as well. This could account for its morphology exhibiting loss of normal reproductive development" (information obtained from B r a s i e r).

\section{REFERENCES}

Garrison R. G, Mariat $F_{+}$, B oyd K. S. Fromentin H. 1977. Ultrastructural observations of an unusual osmophilic body in the hyphae of Sporothrix schenckit and Ceratocystis stenoceras. Ann. Microbiol. 128B: 319-337.

H a 11 J. L., F l o w e r s T. J, R o b e r t s R. M. 1974. Plant cell structure and metabolism: 327-395. London, Longman.

H ow a r d R. J, M a x w e 11 D.P. 1975. Cytology of Ceratocystis ulmi. Phytopathology 65: 816-919.

J e n g S., H u b b e s M. 1980. Utrastructure of Ceratocystis ulmi. I. Hyphae and ascocarp peridium. Eur. J. For. Path. 10: 16-27.

P r z y b y 1 K., M o r el e t M. 1993. Morphological differences between Ophiostoma piceae and $O$. querci isolates. Cryptogamie Mycol. $14 ; 219-228$.

P r z y b y 1 K. 1995. Zamieranie dębów w Polsce. I. Objawy chorobowe i grzyby występujące na nadziemnych organach zamierających dębów Quercus robur L. oraz cechy morfologiczne grzybów Ophiostoma querci i O. piceae. Idee Ekol. 8: 1-96.

Przy by I K., I dzik ows k a K. 1995. Occurrence of endospores within conidia and hyphal cells of morphologically atypical isolates of Ophiostoma querci (Georg.) Nannf. Acta Mycol. 30 (2): 157-165. 


\section{Ultrastrukturalne zmiany w starzejących się zarodnikach i strzępach izolatów Ophiostoma querci}

Obserwacje strzępek i zarodników stadium Sporothrix izolatów Ophostoma querci, na poziomic mikroskopu elektronowego-transmisyjnego przeprowadzono po 6 i 30 dniach hodowli na pożywce maltozowo-peptonowej w temperaturze pokojowej.

Zmiany w ultrastrukturze komórek, będque wynikiem ich starzenia (degeneracji), dotyezyly przede wszystkim budowy cial bloniastych oraz tworzenia endospor. Ciata te w zarodnikach i strzepkach pobranych z grzybni trzydziestodniowych kultur składaly się z elektronowo jasnej matrix, w której występowaly pojedyncze twory przypominające pęcherzyki oraz osmofilne inkluzje i ziarnistosci. Analogiczne zmiany stwierdzono w wakuolach. Natomiast w sześciodniowych kulturach, ciała bloniaste najçę́siej składaly się z kompleksu krótkich membran w postaci cylindrów i pẹcherzyków. Ponadto w zarodnikach i strzępkach tych kultur obserwowano ciala charakteryzujące sic̨ wlóknisto-ziarnistą matrix otoczoną podwójną błoną oraz ciata skladające się z elektronowo ciemnej matrix otoczonej jasną obwódką przypominającł wakuolę.

Endospory stwierdzono w pojedynczych zarodnikach stadium Sporothrix. Z przeprowadzonych badai wynika, ze struktury te najprawdopodobniej tworzyly się wskutek kurczenia cytoplazmy, wokól której następnie powstawaly ściany komórkowe. 